\title{
O medievo e a forja de um adversário: O Islã em Al-Andaluz
}

\author{
The mediaeval and the forge of an opponent: Islam in Al-Andaluz
}

Augusto Machado Rocha*

Palavras-chave:

Representações do Islã

São Eulógio de Córdoba

O Martírio em Al-Andaluz

Keywords:

Islamic Representation

Saint Eulogio of Cordoba

The Martirium in Al-Andaluz
Resumo: Parto da ideia de representação, baseado nos escritos de Chartier e Ginzburg, buscando perceber a definição do ser a partir do não ser, analisando a motivação e contexto de formação da imagem do inimigo muçulmano em Al-Andaluz, a partir dos escritos de Eulógio de Córdoba. Busco demonstrar o papel dos "Mártires de Córdoba" na formação e propagação da representação do Islã - pensando nas formas que uma escrita "local", e seu contexto, oportunizaram uma imagem de aversão à cultura islâmica.

Abstract: From the idea of representation, based on the writings of Chartier and Ginzburg, I'm looking to understand the definition of how to be from not being, analyzing the motivation and the context of the image formation of the Muslim enemy in Al-Andaluz, from the writings. from Eulogio Cordoba I seek to demonstrate or role of the "Martyrs of Cordoba" in shaping and spreading the representation of Islam - thinking of the ways in which "local" writing, and its context, provides an image of aversion to Islamic culture.

Recebido em 09 de março de 2020. Aprovado em 20 de maio de 2020.

\section{Introdução}

$\mathrm{O}$ ano era 851, o território que hoje conhecemos como Espanha estava sob o jugo muçulmano, sendo conhecido como Al-Andalus. Após quase 140 anos de dominação, no emirado de Abd al- Rahman II (822-852), as revoltas internas haviam sido controladas e a administração de Córdoba começou a se solidificar, ampliando seu alcance e poder - a partir do contexto de retração do poder dos Abássidas. Como Jessica Coope (1995, p. 06) afirma, o emir "Abd al Rahman II aproveitou esse inédito contexto de paz e prosperidade para começar a elevar o nível de sua administração e de sua corte perante os Abássidas"'.

Nesse contexto de estabilidade, oferecida pelo Emirado de Córdoba, houve um fortalecimento da comunidade, como um todo, tendo em vista que apesar do jugo muçulmano havia uma forte tolerância e respeito para com os povos do livro. Essa aceitação ao Outro, parte de dois princípios, um religioso e outro político, tendo em vista a existência desse duplo horizonte na sociedade muçulmana, uma fé que se tornou um modelo de administração.

Assim, a aceitação do Islã ao Outro estava baseada no contexto de que "é função da lei islâmica proteger o status privilegiado das minorias, e por isso os templos dos não muçulmanos floresceram em todo o mundo islâmico" (EL HAYEK, 1995, p. 20). A doutrina do Islã impõe o respeito ao espaço das outras crenças, apesar disso não evitar uma dominação político-militar e uma hegemonia da sharia ${ }^{2}$.

Dessa forma, em um contexto de acentuada ascensão do governo muçulmano houve um aumento considerável no número de conversões, tendo em vista a maior segurança e estabilidade que a troca de religião oferecia, por ser a daqueles que detinham o poder. É nesse momento em que começa a se formar um movimento por parte de cristãos que não aceitam o jugo muçulmano, 
buscando o combate a essa estrutura, defendendo "a verdadeira fé". Os ditos mártires de Córdoba ${ }^{3}$, ao atacarem o Islã, buscam construir um discurso e ação que incentive que a comunidade cristã se erga contra os seus dominadores, gerando uma série de representações desses dominadores como uma forma de diminuí-los.

Assim, utilizaremos dos escritos de São Eulógio para compreender a formação da representação do Islã como um mal a ser combatido, levando em conta termos e modos de representar o Outro, o não cristão. Apesar dos mártires não possuírem uma liderança fixa a figura desse santo tornou-se central, tendo em vista os textos que nos legou, como afirma Roldán (2005). É possível perceber, nas palavras de Eulógio, a maneira como não mais enxergava o Islã enquanto apenas uma heresia, mas um poder a ser combatido, em defesa da agredida fé cristã, em seu contexto que coincidiu com o

$22^{\circ}$ ano do reinado de Abdarragman, e naquela época o povo árabe, rico em riqueza e dignidade na Hispânia, havia tomado posse de um domínio infame de quase toda a Península Ibérica, e como em Córdoba, que já se chamará de Patricia e agora chamava de cidade real por residir o monarca. A cidade foi elevada ao topo, exaltada com honras, dilatada em glória, cheia de riquezas e aumentada com abundância de todas as iguarias do mundo, além do que se podia acreditar ou dizer. Era tão assim que em toda pompa terrena ele excedeu e superou aqueles que o precederam enquanto reis. Enquanto isso, sob seu jugo pesado, a Igreja Ortodoxa gemia e era açoitada até sua destruição (FERNÁNDEZ ${ }^{4}$, 1973. p. 398-9) ${ }^{5}$.

\section{O erro daqueles que não lutam e aceitam Alá}

O inimigo muçulmano, então, começa a ser formado através do contraste que ele oferecia, na cidade de Córdoba no século IX. Ao descrever seu tempo São Eulógio destaca o esplendor político, apontando esse como a causa do diminuir da influência cristã em sua região. Em sua narrativa é possível perceber que a construção da representação do outro está embasada em uma perspectiva de dominação simbólica, conceito emprestado de Bourdieu, por Chartier. As representações históricas estão embasadas em relações de poder, onde o que se intenta é o convencimento de lados diversos, quanto ao que seria verdadeiro e correto. Chartier (2002, p. 11) afirma,

essa história define a construção do mundo social como o êxito (ou o fracasso) do trabalho que os grupos efetuam sobre si mesmos - e sobre os outros - para transformar as propriedades objetivas que são comuns a seus membros em uma pertença percebida, mostrada, reconhecida (ou negada). Consequentemente, ela compreende a dominação simbólica como o processo pelo qual os dominados aceitam ou rejeitam as identidades impostas que visam a assegurar e perpetuar seu assujeitamento.

É nesse contexto que percebemos a tentativa de se construir o Outro, perpetrada por Eulógio de Córdoba. Houve, em suas palavras, um interesse de apresentar uma leitura sobre os Outros, que demonstrasse a necessidade de combate ao diferente, ao muçulmano. Foi de tal ação que se resultou o legado de uma representação que, ainda que demore a se firmar, será uma base para a construção de uma verdade quanto ao Outro. Ou seja, em São Eulógio é possível encontrar uma das origens, de uma série de representações, que colocam o Islã no papel de adversários, perversos e que gerou, até hoje, a perpetuação desse valor. É a construção dessa imagem que percebemos ao analisar o Apologeticum martirium, documento que intenta repudiar aqueles que aceitam o Islã e os que são muçulmanos, por crerem na possibilidade de verdade das palavras do Profeta.

É nesse texto, de 857, que o autor aponta Mahomat ${ }^{6}$ como o grande perigo para a sociedade andaluza - a partir de uma nova série de martírios que Eulógio presenciou e que agrediram ainda mais a relação entre cristãos e muçulmanos, ao longo do Emirado de Muhammad I. Assim, esse texto representava uma dupla crítica: ao Islã e, como 
define Roldán (2005, p. 193), “a feroz oposição que boa parte da comunidade cristã estava imprimindo sobre o grupo, cada vez menor, dos apoiadores do martírio".

Ao longo do Apologeticum é possível encontrar uma das primeiras biografias do Profeta, produzidas no Ocidente, ao partir de tal material Eulógio de Córdoba realiza uma série de ataques ao todo do mundo muçulmano. Parte desse monge católico, uma percepção de relativa a origem do poder muçulmano e do papel de seu líder original, ao afirmar que "o abominável profeta Mahomat ocupou o poder por dez anos, ao final deste tempo morreu e foi sepultado no inferno"' (FÉRNANDEZ, 1973. p. 484). Ao partir de tal representação há a construção de uma necessidade, constante, de combater-se o Islã, primeiro enquanto ferramenta de poder na região de Al-Andalus, segundo como religião que além de heresia advinda do Cristianismo é pautada na violência. Pois como afirma Eulógio, ao seguirem seus líderes, era ordenado que os muçulmanos "tomassem em armas e, com um novo ardor por sua fé, ordenava que trucidassem seus adversários"8 (FÉRNANDEZ, 1973, p. 484).

De certa forma, com essas duas citações é possível resumir o modo como Eulógio percebia o Islã: uma falsa religião, criada a partir de um mentiroso e que baseava suas ações na violência. Tal noção é expandida ao longo de seu texto, sendo detalhada na morte de cada mártir, contida no Memorial Sanctorum, e o objetivo é apenas um: fortalecer o Islã enquanto grande inimigo e agressor da cristandade.

Ainda que o grande foco de Eulógio estivesse em atacar e diminuir a comunidade e fé muçulmana, um de seus grandes incentivos esteve vinculado à prática de inferiorizar aqueles que respeitavam e aceitavam a influência do Outro. A crítica aos "falsos cristãos", na perceptiva de Eulógio, pode ser remetida a seguinte percepção do próprio autor, ao ter afirmado que

assim que me lembrei das opiniões daqueles faladores estúpidos, sobre esse assunto, se forma uma opinião apropriada ao alcance de seus conhecimentos, que decide que esses mártires não devem ser reverenciados como antes. [...] Assim, meus leitores, sintam a simplicidade de nossa devoção fiel dedicada ao piedoso Redentor, em defesa de seus mártires e não zombem de nossa obra como más intenções, porque está escrito: 'todo depreciativo será exterminado' ${ }^{9}$ (FÉRNANDEZ, 1973, p. 475-6).

Logo, o que se percebe é que a um duplo percurso no ataque ao Outro. Uma vez que para além da cultura muçulmana e sua estrutura de poder, há o constante ataque aquele que passa a aceitar o Islã, seja convertendo-se, seja opondo-se ao confronto perpetrado pelos mártires. Com relação ao primeiro ponto é possível perceber o incentivo e o interesse pela conversão, ao considerarmos a análise quantitativa de Richard Bulliet (1979, pp. 114-5) percebemos um crescimento exponencial da população adepta ao Islã, na Península Ibérica, especificamente em Al-Andalus. Se em 850 estimouse entre 20 e 30 por cento da população como muçulmana, em 961 acredita-se que o número estava por volta dos $50 \%$ e no ano 1200 esse número seria superior a $90 \%$. Mas, ao retornarmos ao tempo de Eulógio, percebemos que ao repudiar aqueles que discordavam do martírio, ele estava atacando a população cristã que, possivelmente, acreditava na necessidade uma integração ou, ao menos, de uma convivência pacífica. Como o santo aponta, ao descrever as ações e palavras referentes aos "cristãos moderados", ele

acredita que valha a pena enfrentar os ignorantes, antes de expor as virtudes dos mártires, que com uma boca repleta de blasfêmias, insultam os mártires de nosso tempo e afirmam que eles não são iguais aos primeiros mártires. Finalmente, eles afirmam que aqueles pagãos do passado [que atacavam aos cristãos]eram devotados ao culto de estátuas, invadidos pela idolatria de diferentes imagens $\mathrm{e}$ submetidos à monstruosidade de mil ídolos, e que, como muitas formas de coisas terrenas que admiravam, tantas figuras de deuses foram criadas. , na idéia de que o benefício material, pelo qual com suas maiores forças eles 
consumiram seu esforço miserável, não poderia ser obtido de outra maneira senão com um abundante culto às divindades. Enganada por seu erro, a milícia cristã que os enfrentou e se opôs foi punida com cruel perseguição ${ }^{10}$ (FÉRNANDEZ, 1973. p. 477).

Eulógio, dessa forma, buscou a construção de um discurso onde qualquer que fosse o nível de aceitação para com o Outro, tal ato acarretaria um pecado, um erro. Tal percepção foi a base para o fortalecimento de uma representação que coloca o Islã no centro da teia de inimigos que ameaçariam a Igreja. O que percebemos em seu tom é o que Levi afirmou, ou seja, "nenhum sistema normativo é, de fato suficientemente estruturado para eliminar toda possibilidade de escolha consciente, de manipulação ou de interpretação das regras, de negociação" (1989, p. 84). Entende-se a argumentação discursiva do autor cumpria um objetivo específico, ao manipular uma representação de maneira a gerar uma ruptura e um distanciamento entre as diferentes culturas que conviviam na cidade de Córdoba, sob o domínio muçulmano.

O comparativo construído por Eulógio de Córdoba remete ao passado cristão, ao que se refere aos primeiros martírios. Em sua fala, a crítica aponta que da mesma forma que aqueles cristãos davam sua vida ao serem atacados por pagãos, os cordobeses estavam realizando o mesmo, defendendo a cristandade da influência islâmica. Sua intenção, em resposta a seus críticos,

Ao focar no Islã enquanto problemático para a sociedade cristã, Eulógio o definiria enquanto a mais perversa das heresias. Pois em sua perspectiva a crença de Mahomat estaria lidada a ideias idólatras e pagãs, defendendo aquilo que os cristãos atacam. Esse vínculo do Islã enquanto um desvio do Cristianismo é algo comum em autores medievais, tais como Jacopo de Varazze e Arnau de Vilanova, que vinculavam tal crença ao hedonismo.

A problemática de se acreditar, em demasia, nas palavras dessa fonte está centrado no fato de que são escritas ideológicas, onde há o constante objetivo de afastar-se o Outro do convívio. Como Jessica Coope afirma (1995), o que acontecia era que cristãos radicais percebiam toda a realidade do mundo muçulmano como incompatível com o modo de vida cristão. É nesse sentido que Eulógio procurou criticar cristãos moderados (como definido por Coope), que não percebiam a existência de um suplício ou necessidade para a ação dos Mártires de Córdoba. Aqueles que não buscavam o ataque ao Islã compreendiam que os do primórdio do Cristianismo davam a vida em defesa de uma fé em crescimento e expansão, enquanto que os cordobeses atacavam, se sofrerem um ataque direto inicial. Como se percebe, para

cristãos mais moderados, sob sua
perspectiva, percebiam os mártires
e seus apoiadores como criadores
de problema que exageravam as
dificuldades de uma vida sob a lei
Islâmica, arruinando oportunidades
econômicas esociais para os Cristãos em
Córdoba, e incitavam os Muçulmanos a
efetuarem uma maior perseguição. Sob
sua perspectiva, os cristãos radicais,
estavam causando uma emergência,
não respondendo a uma (COOPE,
1995, p. 66).

Podemos notar que era a esse público que as palavras de ataque de Eulógio se dirigiam, tendo em vista que $o$ ataque direto ao Islã era feito de maneira pontuada ao longo de sua escrita, ao descrever o valor dos mártires ou apresentando a fraqueza daqueles que aceitavam a submissão perante Alá, por interesses próprios. As populações contemporâneas desse Santo não se achavam representadas por suas palavras, como nossa bibliografia indica, assim o que ocorre - é a construção de um legado, uma representação do horror islâmico, e daqueles que o aceitam. Nesse sentido há um rosto que simboliza essa aversão ao Islã, o grande eixo de ataque ao Outro estava centrado na figura do Profeta, ou seja, em Mahomat, a personificação do adversário muçulmano.

\section{A Face do Adversário}

$\mathrm{Na}$ concepção de Eulógio o erro no Islã está na figura do Profeta. Sua figura é aproximada com a do AntiCristo. A partir de tal percepção, 
nota-se que falta ao nosso autor o conhecimento da multiplicidade que se encontra na cultura muçulmana. Mas mais do que isso, em sua postura se nota o desinteresse por demonstrar, ou mesmo entender, tal multiplicidade, uma vez que, em seu contexto há um maior enfoque em atacar o Outro.

Tal modelo de descrição em ataque ao Islã, através de seu Profeta, guiou o escrito de Eulógio até o momento de apontar a morte de Mahomat. Como Eulógio descreve o fim do Profeta:

como merecia que acontecesse, a um profeta de grande importância e qualidade, [após sua morte] acabou na barriga dos cães, por ter entregue ao inferno não apenas sua alma como também a de muitos outros. É verdade que cometeu muitos outros crimes que não foram descritos nesse livro, este foi escrito apenas para que os leitores conhecessem tal figura ${ }^{11}$ (FERNÁNDEZ, 1973. p. 486)

É com tal representação que percebemos que a intenção e ação de ataque ao Islã partia da figura do Profeta. Compreende-se um desconhecimento, por parte dos cristãos, do papel de Mahomat, uma vez que com seu modo de descrevê-lo o aproximavam de Cristo, fato incorreto - para o Islã tanto Jesus quanto Mahomat eram nada mais do que homens, ligados ao divino, porém humanos. Como aponta o professor Fernando Muñoz (2014, p. 76),

A grande maioria dos textos sobre a temática islâmica insistem na ideia de explicar o interesse pela biografia de Maomé por razões fundamentalmente ideológicas. De fato, a religião islâmica tendeu a ser explicada a partir da figura, circunstâncias vitais e motivacionais de seu fundador, sendo esses detalhes os mesmos itens biográficos utilizados para refutar o Islã, rebaixando-o a uma categoria de paganismo herético, de origem Cristã, contaminado por judaísmo, idolatria e cristianismo.

Logo, o que ocorre na grande maioria dos textos antigos é o que Eulógio de Córdoba realiza: uma simplificação do Islã ao papel de uma heresia, coordenada por um ser vil, um ministro de Satã, cujo nome é Mahomat. O autor de nossa fonte ainda incorreria na problemática de definir que aqueles que não atacavam o Islã estariam seguindo um falso profeta, "homem louco e endemoniado que arrebatado por um espírito imundo, construiu sua fé como um verdadeiro precursor do AntiCristo"12 (FÉRNANDEZ, 1973, p. 482), e nesse contexto um homem teria sido o responsável pela perdição de toda uma comunidade.

Ao seguirmos a lógica empregada por Eulógio o grande erro de aceitar-se o Islã, seja uma parte ou o todo, estava crer que haveria alguma continuidade entre as ações de tal Profeta e o caminho trilhado por Cristo. Eulógio afirmava que aqueles que acreditavam ser sábios por compreenderem e aceitarem o Islã estavam a viver uma mentira, baseada nos vícios terrenos que afirmava fazer parte do mundo muçulmano.

Ao afirmar que "quem crê e está batizado será salvo, enquanto que aquele que não crê se condenará"13 (FÉRNANDEZ, 1973, p. 480) o autor procurava mostrar qual seria o verdadeiro caminho da fé e quais seriam os desvios e erros. $\mathrm{O}$ que se desejava era que os cristãos assumissem sua crença e não se deixassem acreditar no pecado e erro.

Para atacar o Islã, Eulógio retornava ao tempo do Cristianismo primitivo ${ }^{14}$, no qual julgava encontrar falsos profetas, similares aqueles que povoam os espíritos dos cordobeses, esses guias da fé buscavam construir um caminho de luxúria, mas que inadvertidamente os guiaria para a perdição, no momento do juízo final. Enquanto que a ação dos primeiros mártires era coroada com milagres, necessários sob o ideal de propagação do Cristianismo, aqui o autor procurou mostrar que o espírito martírico havia tomado uma nova forma, de ataque e oposição, antes de uma defesa, propriamente dita. $\mathrm{Na}$ perspectiva de Eulógio, então, os milagres eram um meio para um fim, eles atuavam para firmar a convicção na crença cristã como a correta, algo que já não poderia ser aplicado na realidade de $\mathrm{Al}$-Andalus.

Para nosso autor, o que os seguidores do Islã faziam era distorcer a verdade. Criavam histórias e milagres ligados a figura do Profeta, porém esses não passavam de uma mentira que visava levar a crer na força e santidade desses pecadores. 
Eulógio colocou toda a carga do erro islâmico na figura de seu Profeta, pois acreditava que se não se combatesse o falso, muitos ainda seriam enganados e encaminhados para a perdição. O Islã era temerário por sua falsidade, mas o elemento mais vil dessa comunidade estava centrado, para Eulógio, na figura de Mahomat, o falso profeta.

Há na retórica do santo uma perspectiva de diminuir o Outro, relegando toda a cultura islâmica a um mero desvio herético, perpetrado por um abominável mago, de nome Mahomat. Nesse sentido, ao defender que o martírio seria a prova máxima de devoção e o responsável pelo perdão de todos os erros passados, a intenção de Eulógio seria de mexer com "as racionalidades e as estratégias executadas pelas comunidades, parentelas, famílias e indivíduos" (CHARTIER, 2002, pg. 84) no que se refere aos caminhos da verdade, da riqueza e da pureza - sempre ligando tais ideias a uma filosofia espiritual e não carnal.

Ao focar seu Apologeticus na figura de Mahomat há uma percepção de oferecer um rosto ao adversário islâmico. Ao pessoalizar a crítica ao Islã há um ataque a todos que o seguem e creem que essa possa ser uma fé sequencial ao Cristianismo. O papel de tal representação é ilustrar o fato de que quanto mais "traidores de Cristo" aceitarem esse Outro maior será a possibilidade de um esfacelamento do mundo cristão.

Se a justificativa de muitos seguidores de Cristo estava centrada no fato de perceberem os muçulmanos como pessoas que adoravam a Deus e possuíam uma lei sagrada, Eulógio procurou refletir e justificar que isso não seria possível, pois ainda que o Evangelho tenha se espalhado pelo mundo, jamais deveria se aceitar qualquer alteração da palavra original. Logo, mesmo que haja algo de cristão no Islã, é a sua alteração e desvio que torna essa crença algo mal, vil e que deve ser distanciado e combatido.

Novamente há uma centralidade na figura de Mahomat, para assegurar seu argumento, tendo em vista que Eulógio questionou, "com que lógica deve se crer que um endemoniado e enganador proclame a verdade, que quem está envolvido nos erros de uma lei sagrada possa oferecer bons frutos?" (FÉRNANDEZ, 1973, p. 482). Com esse desenvolvimento Eulógio representou o Islã como erro, um desvio do verdadeiro caminho, definido, por ele e seus companheiros, como o de Cristo.

O que se buscava definir era que "o islã, portanto, não era uma revelação independente, e sim uma heresia, uma forma fracassada de cristianismo, a violenta religião da espada que glorificava a guerra e o assassínio" (ARMSTRONG, 2002, p. 31). O que Eulógio apontou, em seu texto, é refletido por essa citação, uma vez que dentre todos os problemas existentes na crença islâmica o maior estava na construção de uma heresia enquanto religião oficial, guiada por um mentiroso, que levou a redução da fé original. Ao diminuir a verdade cristã, e as leis de Cristo, Eulógio enquadra o Islã em uma crença terrena e vazia, de tal forma que no momento de seu martírio Paulo Álvaro o descreve da seguinte maneira:

O santo lhe disse: 'afia e prepara a espada; para ver se assim, libertando minha alma do corpo a devolvo a quem me deu [...]' E rebate [...] com bastante eloquência a falsidade do Profeta e da religião. [...] O santíssimo mártir contestou ao juiz: 'aí, se pudesse saber o que aguarda aos praticantes de nossa fé, ou se pudesse receber em teu coração o que guardo no meu. Então já não tentaria me dissuadir de meu propósito, mas mais que isso, procuraria se afastar dos prazeres mundanos' (DÍ AZ Y DÍAZ, 1994, p. 149).

A postura de ataque mostra que, para Eulógio, não havia uma possibilidade de representar um Islã múltiplo, mas sim um inimigo. Pois como o próprio autor afirmou em seu Apologeticus, o erro da crença estava muito aquém de uma simples heresia, seu erro estava na figura e ação do Profeta:

Dentre os diversos autores de heresias através da Ascensão apenas este infame, ao fundar por instigação do diabo uma seita de nova superstição, separou-se e distanciou-se da comunidade da Santa Igreja, denegrindo a autoridade da antiga Lei, rechaçando o vaticínio dos profetas, pisoteando a verdade do santo Evangelho e abominando a doutrina 
dos apóstolos; ele, vem transmitindo coisas ridículas, através de sua seita, antes de coisas necessárias. Ensinou, ao blasfemar, que Cristo é a palavra de Deus e seu espírito, que é, sim, um grande profeta, mas desprovido do poder da divindade, semelhante a Adão mas diferente de Deus Pai, e que, próximo do Espírito Santo, por sua santidade realizou milagres e brilhava com sinais e maravilhas, graças ao poder de Deus, sem capacidade de majestade ou divindade própria ${ }^{15}$ (FÉRNANDEZ, 1973, p. 487).

Se Mahomat é o mais vil dos hereges, ao ir além da negação do verdadeiro Cristianismo, como se pode esperar algum bem de uma crença que diminui a figura de Cristo a um mero homem, ligado a Deus, mas sem sua divindade? Parece ser esse o questionamento maior realizado por Eulógio, uma reflexão sobre a falsidade contida no Islã baseada na diminuição que essa crença realizava ao refletir sobre o Cristianismo. Não bastasse o erro ter sido cometido, sua expansão constante estava causando a diminuição da abrangência e aceitação da fé de Cristo, tanto que, em uma de suas críticas finais, o autor focou na diminuição do espaço público destinado aos cristãos. Lamentando pelo grande número de mesquitas que estavam surgindo em Córdoba e ao medonho chamamento para as orações, onde - com mais barulho do que palavras buscavam despertar em toda sociedade o desejo pela mentira - sendo necessário evocar proteção divina para fugir desse horror, de acordo com Eulógio.

Roger Chartier defendeu (2002) que o referencial de qualquer discurso não está pautado "no objeto estável e único" que define, mas sim nas percepções múltiplas que deram origem e apoiam as afirmações quanto ao representado, dessa forma o que está em foco quanto ao discurso é a motivação que o teria originado. Ou seja, Eulógio ataca e afronta toda a estrutura do Islã, principalmente seu Profeta, pois em seu contexto não haveria nenhum inimigo mais prejudicial para a sociedade em que habitava, mas sua motivação ia além.

Em suas palavras havia uma intenção de propagar o Cristianismo e, mais ainda, o de afugentar qualquer aproximação dos seus com esses ímpios "bárbaros". Ao formar uma representação do muçulmano Eulógio legou uma percepção de que o que guia o Islã são os vícios de um homem, e o nome desse é Mahoma - nosso autor, assim, daria rosto e hábitos ao inimigo, criando seu mito político. Tanto é assim, que ao fim de seu Apologeticus, Eulógio afirma que o melhor caminho para conhecer os muçulmanos seria a aproximação com os fiéis, e esse contato seria a prova da vilania do outro, de sua idolatria e perversão. Pois como foi afirmado:

\begin{abstract}
Todo católico deveria conhecer a loucura de seu erro [de Mahomat], os delírios de suas previsões e os pressupostos dessa ímpia nova religião, entenderá os erros com maior claridade investigando outros fiéis da seita, já que, em sua ideia de que tem e creem em algo sagrado, louvando as doutrinas de seu profeta de forma não só privada, mas pública. Muitas coisas, falaram também, alguns escritores nossos, que armados pelos seus por Deus, atacaram esse impuro profeta com sábia pluma ${ }^{16}$ (FÉRNANDEZ, 1973, p. 487).
\end{abstract}

Mahomat era o grande mal, seus seguidores eram hereges que aceitavam uma crença mentirosa. Ao convidar a conhecer o outro Eulógio propunha um olhar e uma perspectiva que se aceita viria apenas a afastar "dois mundos". O mito construído em relação à imagem do Profeta e dos seguidores de Alá era, antes de uma preocupação apenas religiosa, um posicionamento político.

\section{A representação do Islã, um Mito Político}

Como dito, mais do que para seu tempo, Eulógio estava legando uma representação do mundo islâmico como inimigo para o "futuro". Tanto é assim que Ambrósio de Morales, sob desígnio de Felipe II, embase uma versão da identidade espanhola - retomando a luta dos mártires e aos escritos de Eulógio. Assumimos que, um dos papéis do martírio Cordobês, na historiografia, é o de embasar a vitória cristã sobre os inimigos muçulmanos. Tal perspectiva parte do fato de que após o processo de Reconquista Ibérica se buscou 
pela construção de uma identidade, espanhola, que se voltasse para a "ascendência goda para a coroa espanhola, se posicionando contra os mouros e os últimos resquícios que os representavam -, minimizando-os e considerando-os como seres de outro mundo" (LEORNADO, 2015. Pp. 180).

Como Said (2007) afirmou, existe uma construção do Islã enquanto um perigo para o ocidente que foi imposta em um período muito anterior aos arroubos midiáticos dos séculos $\mathrm{XX}$ e XXI. Corrobora com tal percepção a escrita de Eulógio de Córdoba, uma visão que ao atacar esse outro "favoreceu a simplificação sobre o Islamismo". $\mathrm{O}$ que temos em seus três principais textos, o Memoriale sanctorum (escrito entre 851 e 856), o Documentum martyriale (851) e a Apologeticus martyrum (857), é a base para um conjunto de representações desse outro. Pode-se perceber que ainda que esses escritos não tenham surtido um grande efeito em seu período, eles legaram uma imagem do Islã que se solidificou enquanto uma perspectiva de verdade, ainda que irreal.

Percebe-se que a representação do Islã é construída sob uma perspectiva de expor seus vícios e defeitos, pouco se utilizando da percepção que os próprios islâmicos possuíam sobre sua cultura. Escritores cristãos, para além de Eulógio, apresentaram a cultura islâmica da seguinte forma:

Como os cristãos, eles concordam na crença em um só Deus onipotente e criador de todas as coisas. [...] Misturando o verdadeiro com o falso Maomé falsamente pretendia ter recebido [as escrituras] do Espírito Santo. [...] Os sarracenos, que estão mergulhados nas trevas, afirmam que esse pseudoprofeta possui espírito profético superior ao de todos os outros e que teve anjos a ajudá-lo e protegêlo (JACOPO DE VARAZZE, 2003. p. 1008-1009).

Assim, enquanto os muçulmanos percebiam sua cultura como uma fé final, tendo em vista que Maomé seria o último profeta, englobando todos os fiéis que vieram antes, tornando-se uma crença universal, os cristãos a viam como uma heresia. Ao mesmo tempo, percebe-se a permanência de valores similares aos utilizados por Eulógio de Córdoba em um texto do século XIII, produzido por Jacopo de Varazze. Se queremos entender, dessa forma, a motivação para uma determinada representação sobre o outro muçulmano é necessário ter em mente o conceito do "mito político" que se formou em torno desta cultura, mesmo que contrariando aspectos comprovados pela ciência, pois como Blumenberg afirma (1985, p. 67),

ninguém irá afirmar que o mito tem melhores argumentos que a ciência; ninguém irá afirmar que os mitos não tem valia com seus mártires, dogmas e ideologias ou que se possui a intensidade da experiência da fala do misticismo, quando nos voltamos para as ciências. Ainda assim, há algo para se oferecer [no que se refere ao mito] que - mesmo ao diminuir o pedido por certezas, fé, realismo e subjetividade mantêm uma grande satisfação no que se refere à inteligência de expectativas.

Percebe-se que um mito político está baseado no imaginário da crença sobre determinados elementos culturais que foram exagerados em sua formação, aqui teríamos a causa da nossa incorporação da ideia do Islã como grande mal, pela manutenção e exploração da representação deste grande inimigo, oriunda do período medieval. Como afirma Christopher Flood, em seu texto "Political Myth: A Theoretical Indroduction" (1996), o mito político não pode ser compreendido através do primeiro contato, ele é composto pela exposição cumulativa a sua construção - isto explicaria a condensação do poder de um mito, tendo em vista que com poucas imagens ou ícones poderia explicar muito.

Nesse sentido, compreendemos que a representação do Islã, no que se refere à sua interpretação como grande mal, formou-se a partir do Ocidente, sendo mais antiga do que as manchetes de jornais mostram. Retomando Edward Said, o Oriente tornou-se todo o conjunto de coisas que o Ocidente não é (nos campos da cultura, ciências, artes, entre outros aspectos), acarretando uma má representação do Outro, no caso, o oriental. Nesse contexto o papel de Eulógio foi o 
de fomentar uma representação para atacar aqueles que não percebiam o perigo do outro. Pois, como historiadores afirmam, tornou-se uma questão necessária impedir uma hegemonia da cultura árabe-muçulmana, sob a perspectiva de escritores radicais como nosso autor. Tendo em vista que

durante os anos centrais do século IX, a força de todas as terras islâmicas, particularmente em Córdoba, a sede do poder real, fica evidente. Nesta cidade, o crescente esplendor da civilização árabe, e não apenas os muçulmanos, é testemunhado com espanto e orgulho legítimo: muitos cristãos em breve passarão do espanto à administração e, portanto, ao desejo de imitar o novo estilo de vida, de fazer parte desse mundo brilhante e de se integrar a ele, isto é, de se tornar apropriadamente 〈moçárabe〉 (ROLDÁN, 2005, p. 07).

Logo, Eulógio assumia uma postura de combate, pois ao reconhecer a potência que estava se sobrepondo a sua cultura, procurou instigar nos seus uma postura de ataque, constando o mundo cristão a sua representação de um horizonte muçulmano. Como indica Ariel Guiance (2017), Eulógio de Córdoba foi considerado defensor e incentivador do movimento dos mártires da Espanha em suas ações de ataque ao Islã, buscando "demonizar o adversário muçulmano apresentando-o como cruel, libidinoso e apoiador do Anticristo Maomé" (TÓLAN, 2001, p. 41).

Tal postura esteve vinculada a formação de um mito político que se consolidasse como "a verdadeira face" de toda uma cultura. Porém, tal construção esteve baseada em um profundo conhecimento do Islã, ainda que o que se usasse fossem (re)interpretações dessa cultura, para afastar esse outro "do Ocidente", como afirma Jessica Coope: "a ignorância de Eulógio e Álvaro quanto ao Islã era seletiva; seu conhecimento varia de momento a momento, dependendo do argumento específico que desejam suportar" (COOPE, 1995, p. 50).

Define-se que, a representação é o instrumento utilizado por um grupo de indivíduos para criarem um significado para o mundo social, sendo um processo intencional, ela é uma estratégia com objetivos próprios e delimitados, sendo mais do que uma ação cultural, ou seja, um ato político. Soma-se, ainda, a perspectiva da representação ser um discurso e desta forma nunca imbuído de neutralidade, como a construção feita sobre o Islã, sendo dotada de uma intencionalidade que visa suprir um interesse específico. Dessa forma, Eulógio de Córdoba fez uma escolha ao apresentar os inimigos do Cristianismo da maneira como o fez, sendo que sua perspectiva de ataque ao Islã teve uma continuidade muito maior que o caminho escolhido por Álvaro, ao atacar a comunidade judaica, além da muçulmana.

Entende-se o processo que levou a representação construída por Eulógio, bem como suas motivações e escolhas, apresentadas e analisadas ao longo ao artigo. Porém, se essa visão foi perpetuada, tornando-se um mito que denota uma falsa verdade é necessário compreender o processo de assimilação e propagação desse ideário. De tal forma, é necessário realizar uma análise na percepção destinada ao que representou o culto aos mártires, pensando-se no papel de suas relíquias e na exaltação de seus feitos. Tendo em vista que

a formação de um mito político não pode ser percebida apenas pela leitura de histórias que estão colocadas em nossos livros. Para estabelecermos se de fato uma narrativa é ou não um mito político, não é apenas para a produção que devemos olhar, mas sim, acima de tudo, mas sua recepção. É a maneira como a narrativa é recebida que forma o mito político. É o sistema - produçãorecepção-reprodução que constitui 'o trabalho do mito' (BOTTICI; CHALLAND, 2006, p. 321).

Logo, entender o que representou o martírio dos defensores do Cristianismo, na visão de Eulógio, é o caminho para refletir quanto à consolidação de um imaginário quanto ao inimigo muçulmano. Apenas com a experiência de vida dos mártires é possível compreender a motivação do martírio (divisão familiar, negação da fé, entre outras), bem como a representação do Islã, visando compreender qual o papel dessa narrativa, ao pensar no papel dos mártires no combate ao inimigo islâmico. 


\section{Considerações finais}

Ao se analisar um espaço que oferece uma das origens do Islã, enquanto um adversário, percebemos a forma como uma representação pode estar imbuída de uma percepção individual, ao invés de coletiva. Com isso, se afirma a necessidade se realizar uma leitura mais aprofundada com relação ao que foi dito, e ainda se diz, com relação a cultura muçulmana.

Ao se optar por basear a análise nos escritos de Chartier demonstrarmos a necessidade se analisar o espaço do discurso que originou qualquer imagem. A partir do contexto será possível gerar uma análise de impacto, pensando-se nas motivações e consequências para o dito.

Nesse sentido, trazemos como primordial a necessidade de desmistificar-se o Islã, ampliando a percepção que cerca essa fé e cultura, demonstrando a multiplicidade e o modo como se criou um estereótipo que hoje é reproduzido e aceito, quase que sem um questionar. Ao retornar ao medievo, buscamos demonstrar o modo como uma imagem referente ao Islã, enquanto um inimigo, não é recente, logo se levanta problemática de sua aceitação até hoje.

Há uma necessidade, urgente, de se ampliar estudos sobre o Oriente e sobre o Islã. Ainda que aqui tratemos de uma percepção localizada em Al-Andalus seria possível gerar reflexões sobre o contato e representação do Islã em outros contextos. A construção do inimigo islâmico, aqui analisada, demonstra o foco na figura de Mahomat e quais seriam outras formas de construir-se essa representação? De gerar esse ataque?

São Eulógio construiu a figura do "abominável Profeta" para diminuir a influência do Islã em sua comunidade. Instigou o ataque, enquanto havia um interesse pela convivência, com isso se percebe que antes de apenas uma defesa de sua fé, Eulógio buscava por uma hegemonia do poder da ecclesia, frente ao diferente ao Outro. A construção de um inimigo, então, está pautada na necessidade de culpar o ser exterior em virtude dos problemas internos.

\section{Notas}

1 Todas as traduções apresentadas ao longo deste texto, de originais em outros idiomas, foram realizadas pelo autor do artigo.

2 A sharia pode ser compreendida como o conjunto de leis que regem o mundo muçulmano. Ao basear-se no Corão (livro sagrado do Islã) e na sunna e hadiths (textos que remontam a tradição muçulmana e ao exemplo do Profeta), busca apresentar os procedimentos jurídicos dentro do Islã. Como Albert Hourani afirmou (2006, pp. 102), originou-se da necessidade de unificar a tradição, a fé, diferentes princípios morais para ter-se uma lei aplicável ao todo, sendo essa a origem da sharia.

3 Definidos como o grupo de homens e mulheres que, ao contestarem a veracidade da fé Islâmica em praça pública, descumpriam as leis da Dinastia Omíada, que havia se fixado nos territórios de al-Ándalus, que dizia respeito a não criticar os preceitos do Islã pregando um respeito mútuo entre diferentes culturas, e desta forma acabaram sendo executados como punição de seu crime (entre os anos de 850 e 860, na cidade de Córdoba). Tal definição foi compreendida a partir da síntese do pensamento de Albert Hourani (2006) e Karen Armstrong (2002), quanto ao que esse movimento teria representado em seu contexto.

4 A opção por se manter a referência na transcrição realizada por Gil Férnandez parte da perspectiva de ser um dos poucos textos que contém a totalidade das obras de São Eulógio de Córdoba, bem como de outros autores moçárabes (cristãos na Península Ibérica muçulmana). Tendo em vista ser uma transcrição houve a preservação da estrutura e do idioma de nosso autor (latim), preservando a essência do texto.

5 No original: [...] consulatus autem Abdarragman uicesimo nono, cuius temporibus rebus et dignitate gens Arabum in Hispaniis aucta totam paene Hiberiam diro priuilegio occupauit, Cordubam uero, quae olim patricia dicebatur, nunc sessione sua urbem regiam appellatam, summo apice extulit, honoribus sublimauit, gloria dilatauit, diuitiis cumulauit cunctarumque deliciarum mundi affluentia ultra quam credi uel dici fas est uehementius ampliauit, ut in omni pompa saeculari praedecessores generis sui reges excederet, superaret et uinceret, dumque sub eius grauissimo ingo ecclesia orthodoxorum gemns usque ad interitum uapularet.

6 Escolheu-se por manter a grafia apresentada pelo autor original das obras, ou seja, São Eulógio. Tal escolha está baseada no fato de que a real escrita do nome do Profeta seria Muhammad, uma vez que a tradução para Maomé já incorreria em um erro, tendo em vista que não devemos traduzir um nome, optou-se pelo uso do termo utilizado por São Eulógio, para demonstrar com qual representação do Profeta estamos trabalhando. 
7 No original: "Obtinuitque praedictus Mahomat nefandus propheta principatum annis $X$, quibus expletis mortuus est et sepultus inferno".

8 No original: "Arma sibi credentibus assumere iubet et quasi noue fidei zelo ut aduersarios gladio trucidarent instituit"

9 No original: [...] confestim oblatrantium stolidorum opiniones recolens, qui proprium de eo pro captu scientiae ferentes iudicium non, ut prioribus, his quoque reuerentiam martyribus exhibendam esse decernunt, [...] percurrant ego lectores mei simpliciter quod fidelis deuotio nostra in defensione martyrum pio Redemptori dicaui, nec ritu beluino laborem nostrum maliuola intentione subsannent, quoniam scriptum est: 'Omnis detractor eradicabitur.

10 No original: Sed priusquam eorum exequar tropaea insígnia, operae pretium resistere credidi imperetis, qui ore blasfemo horum temporum martyribus derrogantes non esse illos consimiles prioribus martyribus uolunt. Illa denique, aiunt, gentilitas olim simulacrorum cultibus dedita uariisque imaginum sacrilegiis occupata milleno extitit idolorum portento subacta, et quot mundialium mirata est species rerum, tot sibi instituit formas deorum, putans non alias obtinere posse temporarium commodum, ob quod suum miserabilem summis uiribus expendebat conatum, nisi haberet numerosam obseruantiam numinum. Cuius errore decepta crudeli persecutione resistentem ac aduersantem sibi Xpianam uexabat militiam conuiccis.

11 No original: Digne ei quidem accidit ut canum uentrem tantus ac talis propheta repleret, qui non solum suam, sed et multorum animas inferis tradidisset. Multa quidem et alia scelera operatus est, quae non sunt scripta in libro hoc. hoc tantum scriptum est, ut legentes quantus hic fuerit agnoscant

12 No original: cuiusdam pestilentiosi ac daemoniosi homunculi diuinationibus collocantes, qui ab spiritu immundo praereptus iniquitatis mysterium ut uerus Antixpi praecursos exercens, nescio quam nouitatis legem pro suo libito et instinctu daemoniorum perdito uulgo instituit

13 No original: Qui crediderit et baptizatus fuerit, saluus erit; qui uero non crediderit, condemnabitur

14 Como Marcos Caldas (2004) afirmou há uma controvérsia estabelecida quanto a datação do período que conhecemos como "Cristianismo Primitivo", para uns esse período iniciaria imediatamente após a morte de Cristo, enquanto que, para outros, esse período começaria a partir das Epístolas de Paulo para os Tessalônicos. Enquanto que seu fim estaria estabelecido na data de conversão de Constantino, ainda que essa seja incerta.

15 No original: Denique inter ceteros post ascensionem Domini haeresum auctores solus hic infaustus nouae superstitionis sectam instinctu diaboli condens procul ab ecclesiae sanctae conuentu desciscitur, auctoritatem priscae legis infamans, prophetarum uaticinia respuens, sancti euangelii ueritatem conculcans et apostolorum doctrinam detestans, qui ridiculum potius quam rerum necessariarum causas per eandem sectam suam insinuans ore blasphemo docuit Xpm Dei uerbum esse et spiritum eius et prophetam quidem magnum, nulla uero deitatis potentia praeditum, Adae similem, non Deo Patri aequalem, qui ob meritum sancitatis Sancto repletus Spiritu per uirtutem Dei miraculis claruit, signis atque portentis enituit, nihil ex propria maiestate aut deitate praeualens.

16 No original: Cuius quidem erroris insaniam, praedicationis deliramenta et impiae nouitatis praecepta quisquis catholicorum cognoscere cupit, euidentius ab euisdem sectae cultoribus perscrutando aduertet, quoniam sacrum se quippiam tenere et credere autumantes non modo priuatis, sed apertis uocibus uatis sui dogmata praedicant. Multa etiam apud quosdam nostrorum scriptorum inuenie, qui zelo Dei armati aduersus ipsum uatem impudicum prudenti exarserunt stylo.

\section{Referências}

ARMSTRONG, Karen. Maomé: Uma Biografia do Profeta. São Paulo: Cia das Letras, 2002.

BLUMENBERG, Hans. Work on Myth: Studies in Contemporary German Social Thought. Cambridge: MIT Press, 1985.

BOTTICI, Chiara e CHALLAND, Benoit. Rethinking Political Myth: The Clash of Civilization as a Self-Fulfilling Prophecy. European Journal of Social Theory, vol. 9, n. 3, p. 315-226, 2006.

BULLIET, Richard. Conversion to Islam in the Medieval Period. Cambridge: Harvard UP, 1979.

CHARTIER, Roger. À Beira da Falésia: A História entre incertezas e inquietudes. Porto Alegre: Editora UFRGS, 2002.

COOPE, Jessica Ann. The martyrs of Córdoba: community and family conflict in an age of mass conversion. Lincoln: University of Nebraska Press, 1995.

DÍAZ Y DÍAZ, Pedro Rafael. Álvaro de Córdoba: 'Vida de San Eulógio'. Revista Flor: Universidad de Granada, v. 2, p. 127-154, 1993-1994. 
EL HAYEK, S. Compreenda o Islam e os Muçulmanos. São Bernardo dos Campos: Junta de Assistência Social Islâmica Brasileira, 1995.

FERNÁNDEZ, Juan Gil (org.). Corpus scriptorum muzarabicorum. Madrid: Consejo Superior de Investigaciones Científicas, 1973.

FLOOD, Chistopher. Political Myth: A Theoretical Introduction. Nova Iorque: Garland Sciense, 1996.

HOURANI, Albert. Uma História dos Povos Árabes. São Paulo: Cia das Letras, 2006.

JACOPO DE VARAZZE, Legenda áurea - Vida de Santos, tradução Hilário Franco Júnior. São Paulo: Companhia das Letras, 2003.

LEONARDO, María José. El Monumento del Trofeo a los Mártires, en Córdoba, 1588, Elaborado por Ambrosio de Morales. POTESTAS: Estudios del Mundo Clásico e História del Arte. Universitat Jaume I, Castellón, Espanha, v. 08, p. 175-193, 2015.

LEVI, Giovani. Le Pouvoir au village: Histoire d'un exorciste dans le Piémont du XVIIe siècle. Paris: Gallimard, 1989.
MUÑOZ, Fernando González. Apuntes sobre el tratamiento literario del profeta Mahoma en Occidente. In: MONFERRER-SALA, Juan Pedro; MÁRQUEZ, Miguel Rodríguez-Pantoja (Org.). La Cultura clássica y su evolución a través de la Edad Média. Córdoba: Servicio de Publicaciones Universidad de Córdoba. 2014. p. 93-105.

ROLDÁN, Pedro Herrerá. Obras Completas de Eulógio de Córdoba. Madrid: Akal, 2005.

SAID, Edward. Orientalismo: O Oriente como Invenção do Ocidente. São Paulo: Companhia das Letras, 2007.

TÓLAN, John. The legal status of religious minorities in the medieval Medieval Mediterranean world: a comparative study. In: BORGOLTE, Michael. Hybrif Cultures in Medieval Europe: Papers and Workshops of in International Spring School. Akademie Verlag: HAL Archieves - Ouvertes, 2011. p. 141-149. 